\title{
Reproduction of the planktonic copepod Calanus finmarchicus in the Lower St. Lawrence Estuary: relation to the cycle of phytoplankton production and evidence for a Calanus pump
}

\author{
Stéphane Plourde, Jeffrey A. Runge \\ Institut Maurice-Lamontagne, Department of Fisheries and Oceans, CP 1000, Mont-Joli, Québec, Canada G5H $3 Z 4$
}

\begin{abstract}
Due to the dynamic physical environment of the Lower St. Lawrence Estuary, the spring phytoplankton bloom in the Laurentian Channel occurs late in the season, typically in mid-June, but the high phytoplankton biomass is sustained throughout the summer months. In this study, relationships between the phytoplankton production cycle, water temperature, and the reproductive cycle of Calanus finmarchicus Gunnerus, a predominant planktonic copepod in the Lower Estuary, were investigated during spring-summer 1991. Field observations showed that the final stages of oocyte maturation in C. finmarchicus females did not begin until the onset of the spring phytoplankton bloom in midJune. High egg production rates, as estimated by the number of eggs released by females incubated immediately after capture, commenced 1 wk later and persisted until late August. Egg production rates were significantly correlated with an index of gonadal maturity in females and were consistent with a rectilinear or curvilinear relationship with chlorophyll a standing stock. Laboratory experiments showed that: (1) in presence of food (the diatom Thalassiosira weissfloggii), maturation of oocytes would proceed and females could spawn eggs at least 2 mo before the spring bloom; (2) without food, the oocytes did not develop past immature stages, except in a small minority of the population; and (3) colder temperatures in early spring would prolong the lag between the onset of the spring bloom and the start of egg production by less than $4 \mathrm{~d}$. Combined with concurrent microscopic measurements of oil sac volume, the results do not rule out the possibility that lipid reserves were used to support the early stages of oogenesis, but do show that the majority of females did not use lipid reserves for vitellogenesis prior to the spring phytoplankton bloom. It is suggested that the Lower St. Lawrence Estuary is an important region of $C$. finmarchicus production in summer which because of the residual surface circulation, may act as a Calanus 'pump' to influence levels of zooplankton biomass in the Gulf of St. Lawrence and on the shelf off Nova Scotia.
\end{abstract}

KEY WORDS: Calanus $\cdot$ Egg production · Primary production cycle $\cdot$ Zooplankton

\section{INTRODUCTION}

The Lower St. Lawrence Estuary is a long $(200 \mathrm{~km})$, narrow $(50 \mathrm{~km})$ and deep $(350 \mathrm{~m})$ body of water connecting the Upper Estuary, into which the St. Lawrence River flows, with the Gulf of St. Lawrence. The dynamic physical environment of the Lower Estuary has a large influence on the pattern and processes of its marine planktonic inhabitants. Due to the large runoff from the St. Lawrence River, residence times in the surface layer in spring are short (Sinclair et al.
1981) and seeding of diatoms into the surface layer may be restricted during the runoff period (Levasseur et al. 1984). As a consequence, the spring phytoplankton bloom in the Lower Estuary typically does not start until mid-June. However, tidal mixing at the head of the Laurentian Channel supplies nutrients to the surface waters of the Lower Estuary periodically throughout the summer, and the phytoplankton bloom, in which diatoms and dinoflagellates predominate, usually persists into September (Levasseur et al. 1984, Therriault \& Levasseur 1985). 
Calanus finmarchicus is a predominant member of the planktonic copepod community of the Lower St. Lawrence Estuary. Its prominence in this region is even greater than in the coastal northwest Atlantic. This amplified dominance is thought to result principally from the residual circulation, which rapidly exports surface water containing smaller copepods and imports Calanus-rich deep water (Runge \& Simard 1990). How the Calanus that are present in the Lower Estuary in spring respond to the timing of the phytoplankton production cycle is not known with certainty.

Heinrich (1962) classified the life history of Calanus finmarchicus as one in which propagation in spring cannot begin earlier than the vernal development of phytoplankton. His analysis was based primarily on studies conducted in the northeast Atlantic and adjacent seas, in which the spring bloom typically commences sometime between February and early May. In general, subsequent field observations of $C$. finmarchicus and related species in the genus continue to support this conclusion (e.g. Fransz 1975, Runge 1985a, Skjoldal et al. 1987, Diel \& Tande 1992), although there are reports of spawning before the onset of the spring bloom (Marshall \& Orr 1955, Skjoldal et al. 1987, Melle \& Skjoldal 1989, Diel \& Tande 1992). Experimental studies indicate that there is a curvilinear or rectilinear relationship between Calanus egg production rate and external food supply and that females stop producing eggs in the complete absence of food (Marshall \& Orr 1955, Runge 1984, Peterson 1988).

Understanding the response of Calanus finmarchicus to the timing of the spring bloom also requires consideration of its reproductive cycle and of the role of its stored lipids in the production of eggs. Overwintering C5 copepodites typically molt into adults and mate in winter, 1 to 3 mo after solstice (Miller et al. 1991). In the female, the oocyte maturation can begin in stage $C 5$ and continue until a certain point prior to the spring bloom. The role of stored lipids during oogenesis is still in need of clarification. Tande (1982) concluded that the source of materials and energy for sexual differentiation, molting and the first stages of gonad maturation is the female's lipid reserves, but that the final stages of oogenesis, in which large quantities of yolk are accreted, require materials derived from feeding on sufficiently high phytoplankton concentrations. However, it has also been proposed that lipid reserves are sufficient to sustain considerable egg production without an external food supply (Gatten et al. 1979, 1980), which may account for observations of spawning in $C$. finmarchicus before the spring bloom. Diel \& Tande (1992) suggested that there is a direct relationship between the level of lipid reserves at the initiation of gonadal development and the stage of oocyte maturation achieved at the time of the spring bloom.
We present here a study of the reproductive response of Calanus finmarchicus to the unusual primary production cycle in the Lower St. Lawrence Estuary. Laboratory experiments and field observations were employed to address the following 5 questions: (1) What is the relationship between oocyte development and the timing of the spring phytoplankton bloom? (2) Does the start of spawning correspond with the onset of the spring bloom? (3) Does the high phytoplankton biomass in the Lower Estuary sustain egg production by $C$. finmarchicus throughout the summer months? (4) What is the relationship between lipid reserves and oocyte development? (5) How might temperature variation in spring influence oocyte development and consequently the response of $C$. finmarchicus to the spring bloom? Our results lead to the conclusion that the Lower Estuary functions as a Calanus 'pump', which may have important implications for understanding zooplankton population dynamics in the Gulf of St. Lawrence and perhaps on the coastal shelf of Nova Scotia.

\section{METHODS}

Observations in the Lower Estuary. The field work was conducted at a single station (330 m depth) located in the Laurentian Channel approximately $16 \mathrm{~km} \mathrm{~N}$ of Rimouski $\left(48^{\circ} 40^{\prime} \mathrm{N}, 68^{\circ} 35^{\prime} \mathrm{W}\right.$; Fig. 1). The protocol for each of 28 visits to the station between 18 April and 26 August 1991 included a CTD profile (Applied Microsystems STD-12) from 0 to $250 \mathrm{~m}$, collection of water samples with a Niskin bottle at 0,10 and $20 \mathrm{~m}$, and collection of zooplankton with a $1 \mathrm{~m}$ diameter, $3.33 \mu \mathrm{m}$ mesh plankton net towed at $<30 \mathrm{~m} \mathrm{~min}^{-1}$ from $250 \mathrm{~m}$ to the surface. The water samples were transferred to dark bottles and the zooplankton, which were captured in a large (8 1), restricted-flow cod end, were immediately diluted into 41 jars filled with filtered seawater. The bottles and jars of zooplankton were kept at 5 to $6^{\circ} \mathrm{C}$ in coolers during transport to the laboratory at the Maurice-Lamontagne Institute, Mont-Joli. Sampling was consistently done between 10:00 and 12:00 h and laboratory analyses (filtrations, sorting for experiments) typically began between $14: 00$ and 14:30 h. On 2 final sampling visits to the station $\{2$ and 9 September), only a net tow was taken, and the zooplankton catch was preserved in $4 \%$ formaldehyde.

In the laboratory, 250 to $750 \mathrm{ml}$ subsamples from each water bottle were filtered in duplicate on $\mathrm{GF} / \mathrm{F}$ filters and $5 \mu \mathrm{m}$ Nuclepore screens. The screens and filters were extracted in acetone at $5^{\circ} \mathrm{C}$ for 16 to $24 \mathrm{~h}$, the extract analysed on a Turner Designs model 112 fluorometer, and chlorophyll a concentrations calculated according to Parsons et al. (1984). Within 1 to $3 \mathrm{~h}$ 


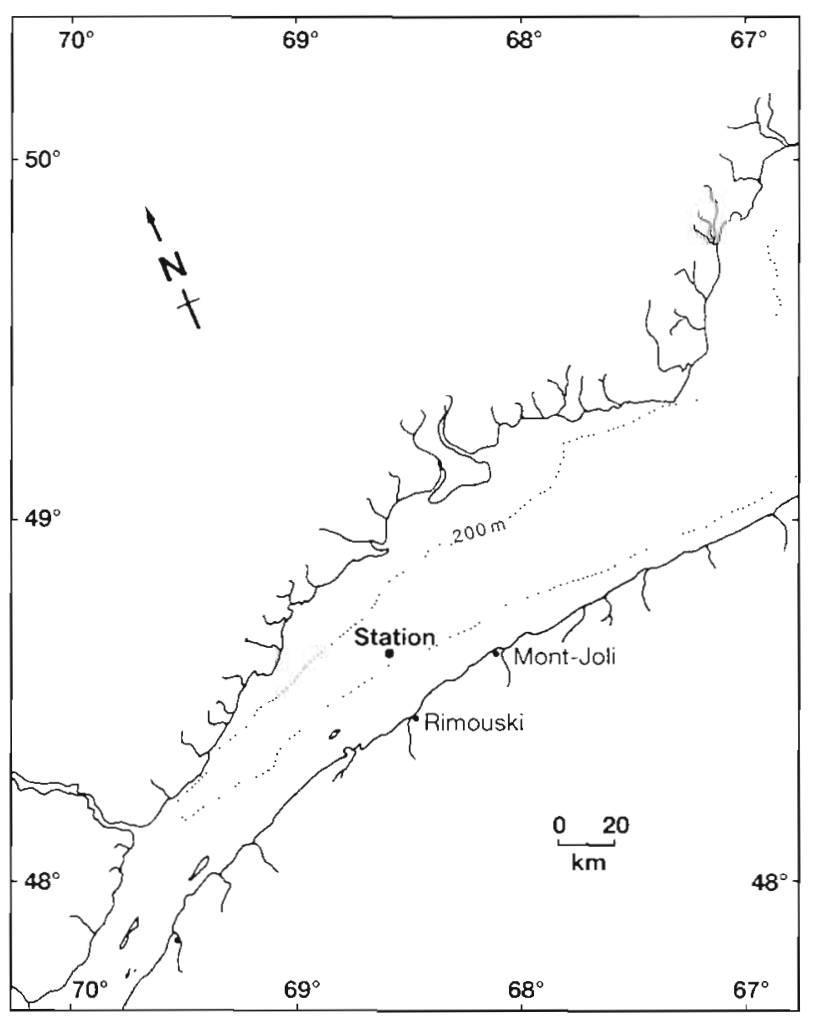

Fig. 1. Sampling station location off Rimouski in the Lower St. Lawrence Estuary

of arrival, approximately 200 Calanus finmarchicus females were sorted from the live zooplankton using a dissecting microscope. Only females smaller than $3.32 \mathrm{~mm}$ in prosome length were selected; larger copepods were assumed to be $C$. glacialis, which were also present although usually much less abundant. Most of these larger females had red-pigmented genital pores, which facilitated identification. C. glacialis eggs, which are distinctly different from those of $C$. finmarchicus (McLaren et al. 1988), were extremely rare in our incubation experiments, confirming the accuracy of our selection technique. Immediately after sorting, 30 females were preserved in $4 \%$ formaldehyde with BHT added, for later measurement of stages of oocyte development and oil sac volume. The remaining females were used for the measurement of egg production rate.

Egg production rates of Calanus finmarchicus were determined by incubating females over a $24 \mathrm{~h}$ period in $1 \mathrm{l}$ egg separation containers, as described in Runge (1985b). The containers consisted of plexiglass cylinders closed off on the bottom end with a $571 \mu \mathrm{m}$ mesh nitex screen and immersed in 21 glass beakers containing $0.2 \mu \mathrm{m}$ filtered seawater. Four different incubation conditions, involving 2 food treatments (enriched and filtered seawater) and 2 temperature regimes
( 1 and $5.5^{\circ} \mathrm{C}$ ) were employed. Once a day, the enriched treatments received approximately 8000 cells $\mathrm{ml}^{-1}$ of the diatom Thalassiosira weissflogii (in exponential growth), which was cultured at $15^{\circ} \mathrm{C}$ in 401 plastic bags using natural seawater (filtered at $0.2 \mu \mathrm{m}$ ) enriched with f/2 medium (Stein 1973). Salinity of the seawater used in laboratory experiments and cultures ranged between 25 and 30 PSU (Practical Salinity Units). Ten female $C$. finmarchicus were placed into each container and there were 4 replicate containers per treatment. The incubations typically started between 15:00 and 17:00 h. After $24 \mathrm{~h}$, the females were removed and the eggs, which were left behind in the beakers, were counted.

Laboratory experiments. Females for laboratory experiments were collected at the station from 8 to 12 April 1991. To study the effect of temperature and food regime on gonad maturation and lipid utilization rates, 2400 females were distributed among twenty-four 41 containers (100 females container ${ }^{-1}$ ), which were then randomly allocated to 1 of the 4 treatments described above. Every 2 d the medium in each container was renewed. On the alternate days, the algal concentration in the enriched containers was assessed with a Coulter Counter TAII and Thalassiosira weissflogii culture was added to obtain 8000 cells $\mathrm{ml}^{-1}$. For the first $14 \mathrm{~d}$ of the experiment, 30 females treatment ${ }^{-1}$ (6 females container ${ }^{-1}$ ) were removed during medium changes. For the remainder of the experiment, females were removed every 3 to $4 \mathrm{~d}$. The females were preserved in $4 \%$ formaldyde with BHT added.

Egg production rates were measured during the same period, using the basic methodology described above (10 females container ${ }^{-1}$ ). Each day, the females in their egg separator were placed in a new beaker filled with fresh medium and the number of released eggs was recorded. Both sets of experiments commenced on 14 April. The containers were kept in controlled temperature rooms in the dark for the duration of the experiment.

Stages of oocyte maturity. The classification of stages of oocyte maturity in female Calanus finmarchicus followed descriptions provided by Runge (1987) and Tourangeau \& Runge (1991). Females were classified according to the most advanced stage of oocyte maturity observed in the reproductive tract. Evaluations were made under a Wild M-8 binocular microscope at $25 \times$. Copepods carrying only pre-vitellogenic and early vitellogenic oocytes (stages 1 to 3 ) were considered to be in a non-spawning or pre-spawning state. Females in stages 4 to 7 were classified as actively spawning because of the presence of oocytes undergoing secondary vitellogenesis.

Lipid reserves. Following Arts \& Evans (1991), female lipid reserves were estimated from oil sac 
volume. A BIOQUANT image analysis system coupled to a binocular microscope and video monitor was used to measure body and oil sac dimensions, in lateral view, of the same females preserved for assesment of oocyte development. Volumes were calculated assuming that both oil sac and prosome were ellipses, according to the formula:

$$
V=(4 / 3) \pi(A / 2)(B / 2)(C / 2)
$$

where $A=$ maximum length; $B=$ height; and $C=$ width. Based on observations that the transversal shape of both objects is nearly circular, $C$ was assumed to be equal to $B$. Oil sac volume was divided by prosome volume in order to normalize the effect of body size. The data are presented as the mean of individual relative oil sac volume in each sample.

\section{RESULTS}

\section{Reproduction of Calanus finmarchicus in the laboratory}

Food and temperature strongly influenced long-term egg production of Calanus finmarchicus in the laboratory incubations (Fig. 2A, B). Daily egg production rates in filtered seawater were typically zero and never exceeded 5 eggs female ${ }^{-1} \mathrm{~d}^{-1}$. Egg production rates in food-enriched seawater were consistently higher at $5.5^{\circ} \mathrm{C}$ than at $1^{\circ} \mathrm{C}$ (ANOVA, $p<0.025$ ) except for the last $17 \mathrm{~d}$, when they were approximately equal (ANOVA, $p>0.3)$. Rates were highest in the first 3 wk of the experiments; maximum daily egg production (43 eggs female $\mathrm{d}^{-1}$ at $5.5^{\circ} \mathrm{C}$ and 30 eggs female $\mathrm{e}^{-1} \mathrm{~d}^{-1}$ at $1^{\circ} \mathrm{C}$ ) occurred on Day 9 and 13, respectively, of the experiment. Mean total egg production in enriched seawater over the 2 mo period was 913 eggs female ${ }^{-1}$ at $5.5^{\circ} \mathrm{C}$ and

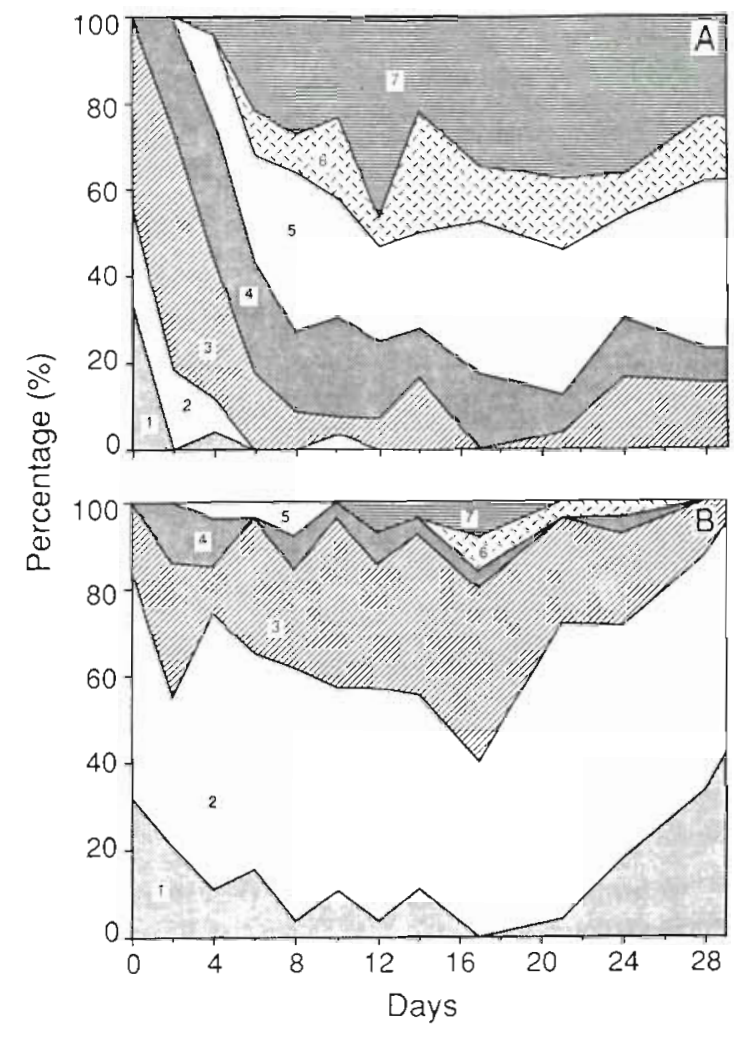

Fig. 3. Calanus finmarchicus. Gonad maturation (proportion of total population in each stage) of females in laboratory experiment (14 April and $13 \mathrm{May} 1991$ ) at $5.5^{\circ} \mathrm{C}$ in (A) enriched and $(B)$ filtered seawater. No. of females per sampling date $=23$ to 33

523 at $1^{\circ} \mathrm{C}$. Total egg production in filtered seawater was negligible in both temperature regimes.

These results are consistent with our observations of gonad maturation in the laboratory population. At the start of the experiment, oocytes of all females were immature (stages 1 to 3 ; Fig, 3). After 6 to $7 \mathrm{~d}$, >80\%
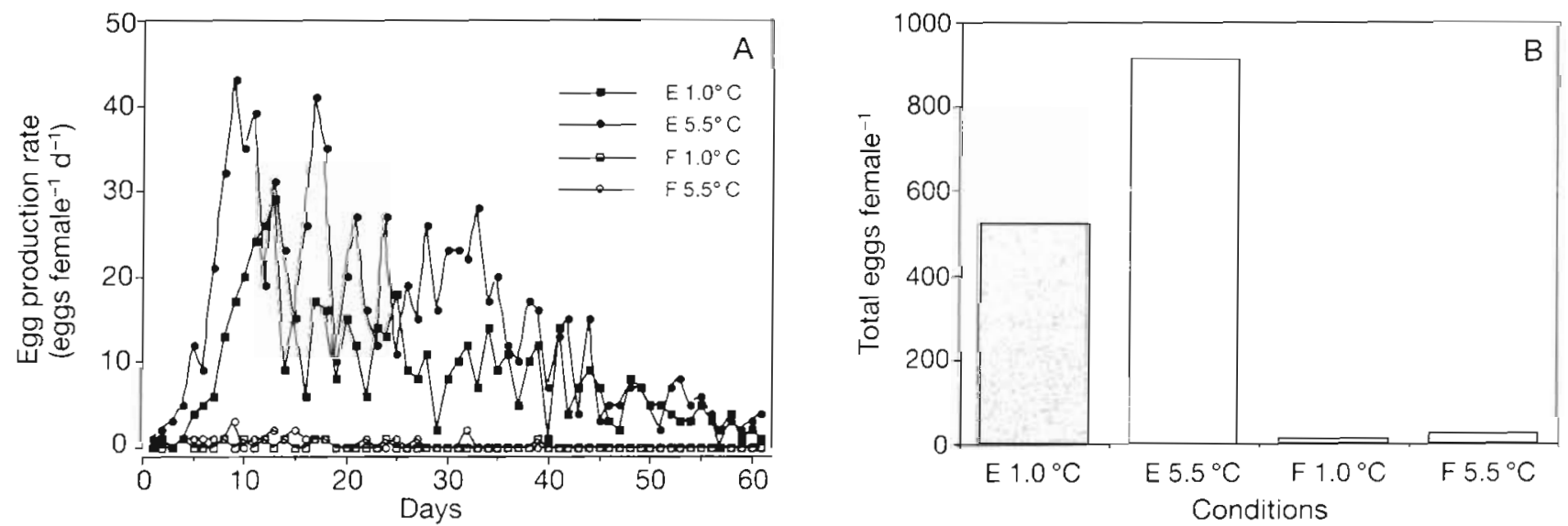

Fig. 2. Calanus finmarchicus. Egg production of females during the laboratory experiment between 14 April and 13 June 1991 (A) Egg production rate in food-enriched (E) and filtered (F) seawater at 1 and $5.5^{\circ} \mathrm{C}$. Points represent mean of 31 to 40 females (B) Total egg production per female for the $61 \mathrm{~d}$ of experiment in the 4 treatments 

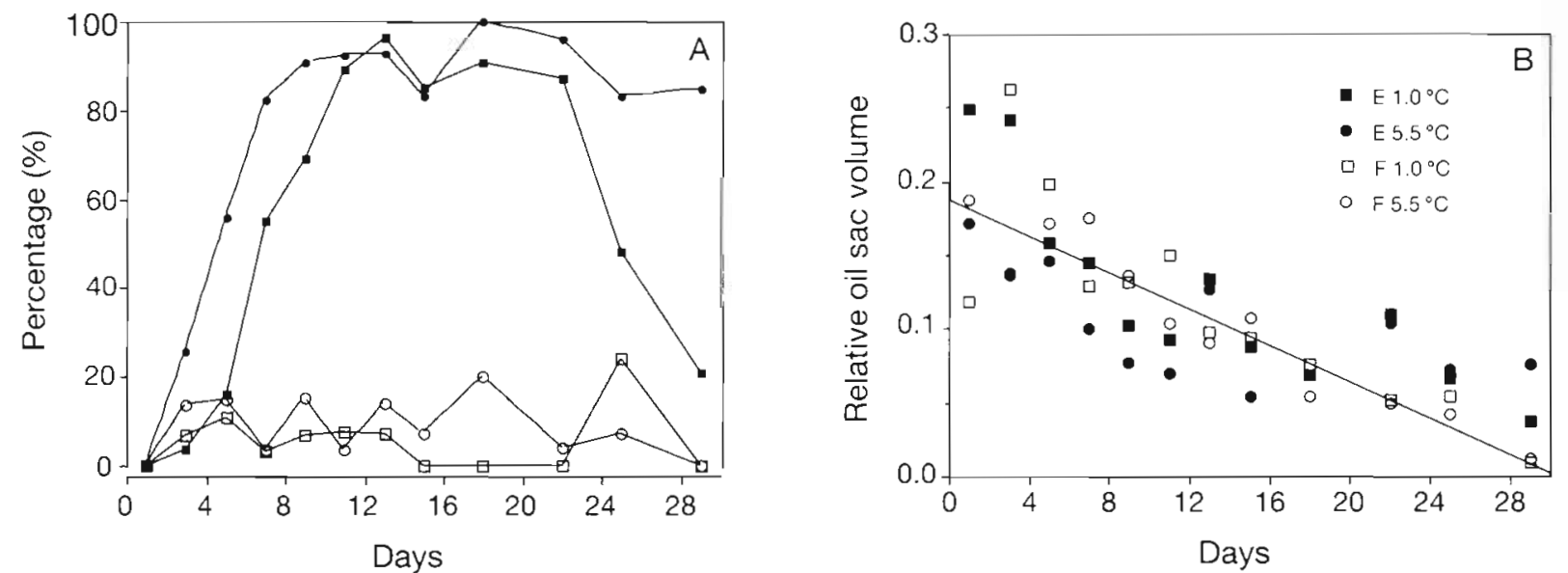

Fig. 4. Calanus finmarchicus. Laboratory experiment with females (14 April to 13 June 1991). (A) Percentage reproductive (stages 4 to 7) females in the 4 experimental conditions. For each point, $n=23$ to 33. (B) Relative oil sac volume (oil sac volume (prosome volume) ${ }^{-1}$ ] for the same individuals in food-enriched $(E)$ and filtered $(F)$ seawater. Equation of the regression line: $y=0.187-0.006 x, r^{2}=0.90$

of females in food-enriched seawater at $5.5^{\circ} \mathrm{C}$ carried oocytes that were in the process of or had completed vitellogenesis (stages 4 to 7; Fig. 3A). A similar oocyte development was observed at $1{ }^{\circ} \mathrm{C}$, but with a delay of $5 \mathrm{~d}$ (Fig. 4A). The start of maximum egg production in the laboratory population coincided with the timing of gonad development (cf. Figs. 2A \& 4A). In the filtered seawater treatments, oogenesis did not progress and the majority $(>80 \%)$ of the females remained immature at both temperatures (Figs. 3B \& 4A). However, in a small proportion of the population (ca 15\%), oocytes proceeded to maturity despite the absence of food.
The relative oil sac volume decreased steadily, from approximately $20 \%$ at capture to $<5 \%$ after 2 mo in all treatments (Fig. 4B). There was no detectable effect of food or temperature on the rate of decline (ANCOVA, $\mathrm{p}>0.3$ ).

\section{Reproduction of Calanus finmarchicus in the Lower St. Lawrence Estuary}

Representative temperature and salinity profiles during the study period are shown in Fig. 5. Surface temperature rose from $4{ }^{\circ} \mathrm{C}$ in mid-May to between 8 and $9^{\circ} \mathrm{C}$ in August. The upper depth of the intermediate water, a layer of cold $(-0.5$ to $1^{\circ} \mathrm{C}$ ) water which is characteristic of the Lower Estuary in summer (Koutitonsky \& Budgen 1991), varied between 30 and $75 \mathrm{~m}$. Salinities at the surface were as low as 24 PSU, reflecting discharge of spring runoff from the St. Lawrence River in early summer, but were consistently 32 to 33 PSU deeper in the water column.

In 1991, the transition from low to high phytoplankton biomass took place within a $10 \mathrm{~d}$ interval in midJune, marking a distinct beginning to the spring phytoplankton bloom. A prolonged, summertime period of high phytoplankton biomass ensued (Fig. 6A). Between June 13 and August 15, integrated chlorophyll a concentrations over the first $20 \mathrm{~m}$ of the water column were typically between 75 and $125 \mathrm{mg} \mathrm{m}^{-2}$.
Fig. 5. Temperature and salinity profiles $(0$ to $60 \mathrm{~m}$ only; station depth $330 \mathrm{~m}$ ) on 30 May, 13 June and 26 August 1991 at the sampling station 

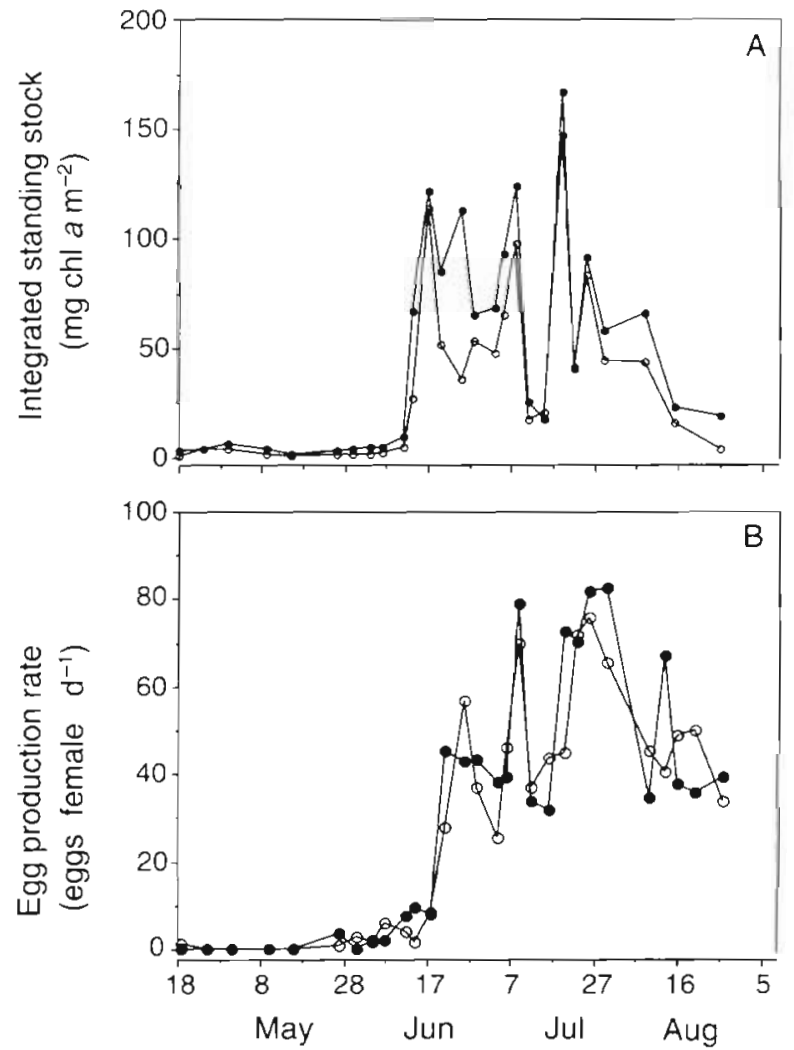

Fig. 6. Calanus finmarchicus. Time series from the Lower St Lawrence Estuary station between 18 April and 26 August 1.991 (A) Estimated integrated total (•) and $>5 \mu \mathrm{m}(0) \mathrm{chl}$ a ( $\mathrm{mg} \mathrm{m} \mathrm{m}^{-2}$ ) standing stock for the first $20 \mathrm{~m}$ of the water column. (B) Estimated in situ egg production rate of females at $5.5^{\circ} \mathrm{C}$ in enriched ( $\bullet$ and filtered (o) seawater. Points represent mean of 4 replicates

Maximum values (up to $166 \mathrm{mg} \mathrm{chl} \mathrm{a} \mathrm{m}^{-2}$ ) were observed in July. During this period, algae $>5 \mu \mathrm{m}$ constituted more than $50 \%$ of the phytoplankton biomass. By late August, values were smaller than $25 \mathrm{mg} \mathrm{m}^{-2}$, indicating that chlorophyll concentrations had started to decline.

The spawning of Calanus finmarchicus was synchronised with the timing of the phytoplankton bloom (Fig. 6). Observations showed zero or near-zero egg laying in the Lower Estuary between mid-April (the start of the study) and the end of May. Some egg production occurred at the beginning of June, but rates for the population remained. low $\left(<10\right.$ eggs female $\left.{ }^{-1} \mathrm{~d}^{-1}\right)$. Egg production rates increased dramatically in the third week in June, 7 to $8 \mathrm{~d}$ after the distinct rise in phytoplankton biomass. C. finmarchicus continued to produce eggs at high rates (between 22 and 82 eggs female $e^{-1} d^{-1}$ ) until the end of August. Highest rates were observed in July (Fig. 6B).

The short-term (24 h) incubations employed to estimate egg production were conducted at 2 different temperatures and food treatments. Females held at
$1{ }^{\circ} \mathrm{C}$ released $24 \%$ fewer eggs (ANOVA, $\mathrm{p}<0.025$ ), on average, as compared to those maintained at $5.5^{\circ} \mathrm{C}$. However, the general seasonal pattern of egg production did not vary significantly between temperatures (Fig. 6B). Except for the period of rapid increase in phytoplankton biomass in mid-June, females incubated in food-enriched or filtered seawater released the same number of eggs (ANOVA, $\mathrm{p}>0.3$ ).

The fluctuations in egg production rate in summer, after the onset of the bloom, were not well correlated with variations in phytoplankton biomass (Fig. 6). When the 2 data points taken between 13 and 17 June (when egg production rates had not yet equilibrated with the rapid increase in food concentration) are removed, the relationship between egg production and chlorophyll biomass is consistent with a curvilinear or rectilinear response to food concentration (Fig. 7).

Changes in gonadal maturity in the population (Fig. 8A) match the observations of egg production rates. There were 4 distinct phases in the seasonal cycle of gonad maturation. An increase, from 10 to $35 \%$, in the proportion of stage 3 females and a corresponding decrease in the proportion of stage 1 females occurred during the period prior to the spring bloom. Females carrying oocytes in advanced stages of vitellogenesis (stages 4 to 7 ) made up less than $20 \%$ of the population. The second phase started with the spring bloom on 12 June and lasted for $1 \mathrm{wk}$, during which more than $80 \%$ of the female population attained reproductive maturity. This period corresponds to the

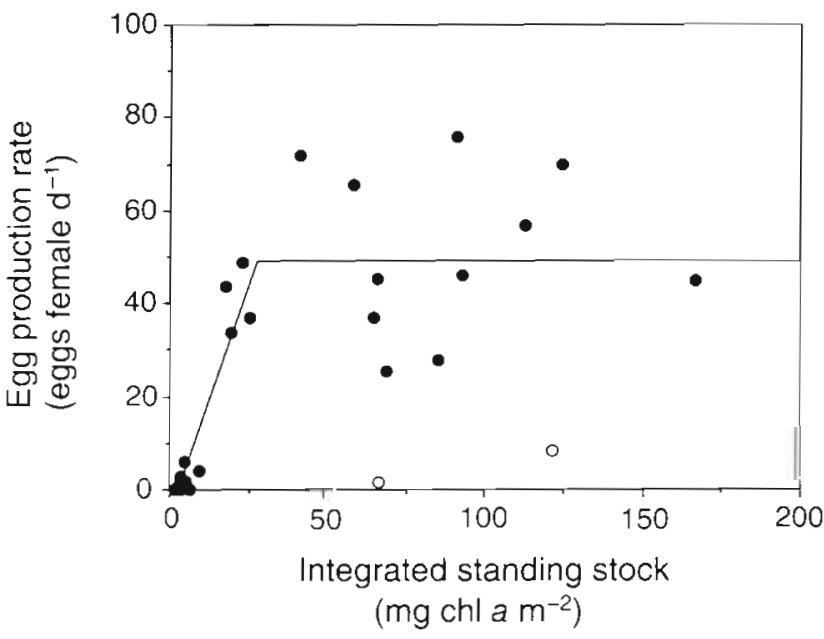

Fig. 7. Calanus finmarchicus. Estimated in situ egg production rate of females in the Lower St. Lawrence Estuary in 1991 as a function of the total chl a concentration $\left(\mathrm{mg} \mathrm{m}^{-2}\right)$ integrated over the first $20 \mathrm{~m}$ of the water column. Data are fit to a rectilinear model: $y=2.00 x-6.00$ (for $x<50 \mathrm{mg} c h l a \mathrm{~m}^{-2}$ ), $\mathrm{r}^{2}=0.93 ; y=49.4$ (for $x \geq 50 \mathrm{mg}$ chl a m $\mathrm{m}^{-2}$ ). The 2 measurements $(0)$ taken during the lag between the rapid increase in food concentration and the increase in egg production ( 13 to 19 June) are not included in the fit 

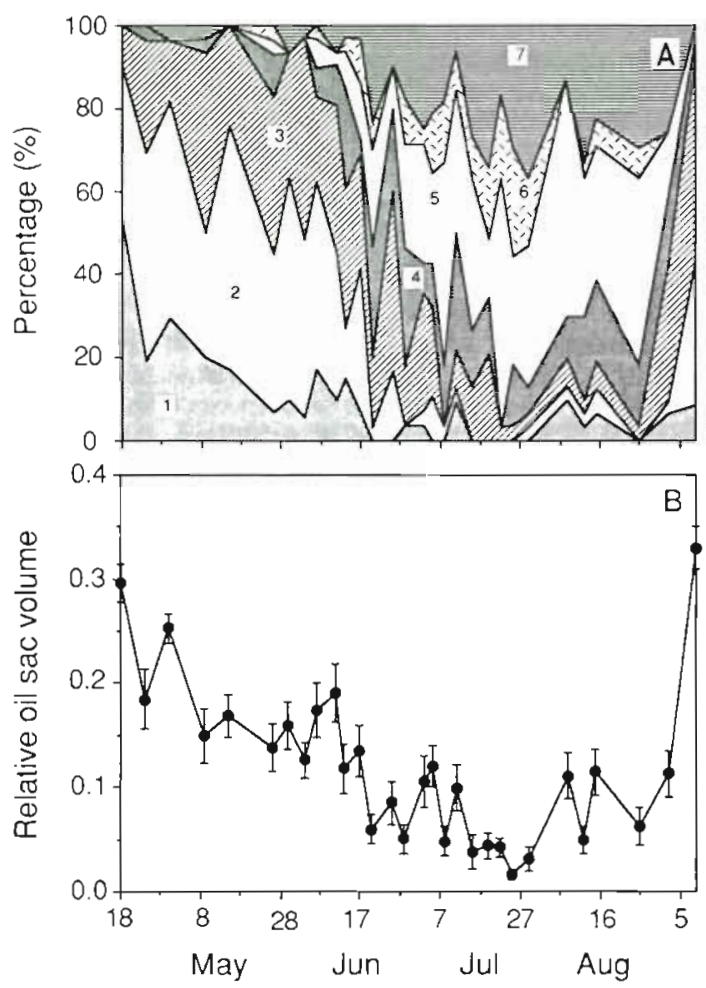

Fig. 8. Calanus finmarchicus. Time series from the Lower St. Lawrence Estuary station between 18 April and 9 September 1991 of (A) gonad maturation stages of females and (B) relative oil sac volume for the same individuals. No. of females per sample $=22$ to 42

lag time between the onset of high phytoplankton biomass and the start of high egg production rates. The third phase, during which most of the females were reproductively mature, corresponds to the period of high summer egg production (21 June to 31 August). The final phase shows a marked decline in the proportion of reproductively active females between 31 August and 9 September, signaling the end of the reproductive season.

The empirical relationship between egg production rates and the state of reproductive maturity of the population is shown in Fig. 9. Following Runge (1987), estimates of in situ egg production rate in filtered seawater at $5.5^{\circ} \mathrm{C}$ were regressed on an index of reproductive maturity (the cumulative proportion of the female population in stages 4 to 7 ). A simple linear regression showed a strong correlation between the 2 variables $\left(\mathrm{r}^{2}=0.79\right)$.

The relative oil sac volume followed a similar 4phase pattern over the sampling period (Fig. 8B). During the interval prior to the spring phytoplankton bloom, the oil sac/body volume ratio decreased from an initial value of 0.3 to about 0.17 to 0.20 , a reduction of 30 to $40 \%$. The decrease was most noticeable in late April-early May, when there was also a marked

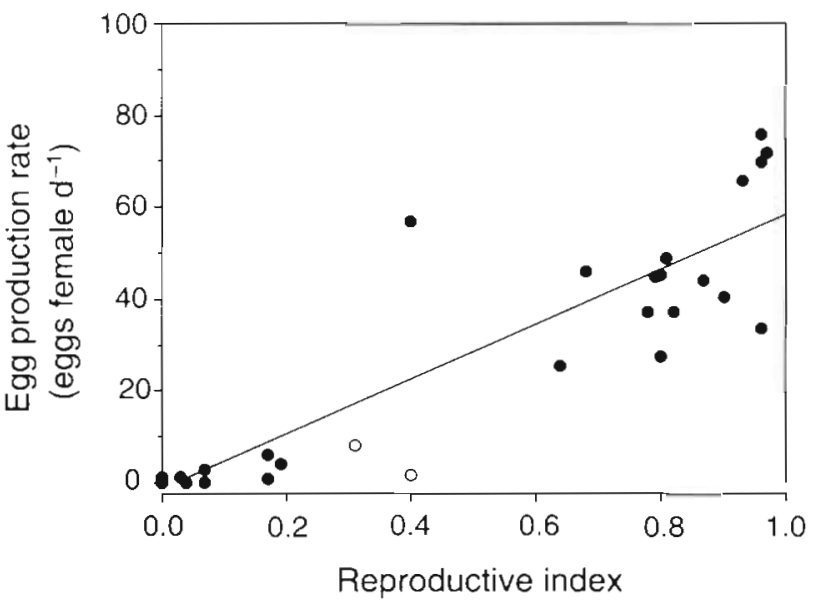

Fig. 9. Calanus finmarchicus. Relationship between in situ egg production rate at $5.5^{\circ} \mathrm{C}$ in filtered seawater and reproductive index (proportion of females, stages 4 to 7 inclusive) for females in the Lower St. Lawrence Estuary, 1991. The equation is a simple linear regression: $y=59.8 x-1.6\left(\mathrm{r}^{2}=\right.$ 0.79 ). The 2 measurements (o) taken during the lag between the rapid increase in food concentration and the increase in egg production ( 13 to 19 June) are not included in the fit. The regression of egg production rate on reproductive index, using enriched seawater at $5.5^{\circ} \mathrm{C}$ (data not shown) is: $y=68.0 x-3.4\left(\mathrm{r}^{2}=0.80\right)$

decrease in the proportion of gonadal stage 1 females. A pronounced decline in oil sac volume occurred during the phase of rapid gonad maturation corresponding to the onset of the spring bloom. By 3 July, the oil sac was about $25 \%$ of the volume it had $3 \mathrm{wk}$ earlier. Its longitudinal axis no longer extended the length of the cephalothorax, but rather was reduced to the posterior end. During the phase of high summer egg production, the oil sac was thin, making up only 5 to $10 \%$ of the prosome volume, and confined to the posterior end of the cephalothorax. In September, after mature stages disappeared from the population, oil sac volume increased to high pre-reproductive values.

\section{DISCUSSION}

\section{Oocyte development, egg production, and the cycle of phytoplankton production in the Lower Estuary}

The results are consistent with the prevailing understanding of the relationship between egg production and external food supply for Calanus finmarchicus and related species of the genus. Based on the correspondance of egg production with the spring bloom and confirmed by feeding experiments reported elsewhere (Ohman \& Runge in press), females in the Lower Estuary relied on ingested phytoplankton as the source of materials for the final stages of oocyte maturation. Egg 
production commenced with the late spring bloom, after a $1 \mathrm{wk}$ lag corresponding to the time required for the oocytes to complete vitellogenesis. High phytoplankton concentrations apparently supported egg production throughout the summer.

There is a clear relationship between oocyte maturation and egg production (e.g. Fig 9), supporting the proposal that egg production rates of Calanus finmarchicus can be predicted from preserved samples of females staged for reproductive maturity (Runge 1987). The slope of the linear regression (59.8) is about $50 \%$ greater than the value obtained by Runge (1987) for C. finmarchicus on the Scotian shelf. However, the females from the Lower Estuary were considerably larger (2.9 to $3.1 \mathrm{~mm}$ mean prosome length; unpubl. data) than their counterparts in waters off Nova Scotia ( 2.7 to $2.8 \mathrm{~mm})$. This difference in body size is sufficient to account for the high rates (60 to 80 eggs female $e^{-1} \mathrm{~d}^{-1}$ ) observed in July in the Lower Estuary, compared to measurements of egg production (using a similar method) in the southwest Nova Scotia population (20 to 40 eggs female $\mathrm{e}^{-1} \mathrm{~d}^{-1}$; Runge 1985b), or in populations in fjords of Northern Norway $(20$ to 35 eggs female $\mathrm{d}^{-1}$ ), where female body size was smaller (2.5 mm prosome length; Diel \& Tande 1992). Given an egg carbon weight of $0.23 \mu \mathrm{g}$ and a female carbon weight ranging between 160 and $220 \mu \mathrm{g}$ (pers. obs., Ohman \& Runge in press), maximum egg production rates in the Lower Estuary in July and August, when surface temperature were 7 to $9^{\circ} \mathrm{C}$, were on the order of 0.08 to $0.11 \mu \mathrm{g} \mathrm{C}$ egg $\mu \mathrm{g} \mathrm{C}^{-1} \mathrm{~d}^{-1}$. This is a reasonable $P / B$ range for these temperatures based on previous experiments (Runge 1984, 1985a). It is therefore not clear that a general relationship can be found that is applicable to all Calanus populations; our results nevertheless advance the possibility of developing a specific relationship for a given region.

The relationship between egg production rate and integrated standing stock indicates that the critical density for maximum rates occurred at about $25 \mathrm{mg}$ chl a $\mathrm{m}^{-2}$ (Fig. 7). Even taking into account that the Lower Estuary value represents just the upper $20 \mathrm{~m}$ of the water column, this is considerably lower than what Runge (1985a) found for Calanus pacificus in Puget Sound and is consistent with the suggestion, based on few data, that the empirical response of the 2 species to chlorophyll standing stock is different (Runge 1985b). In addition to possible species-specific differences in the functional response to 'optimal' food, any number of factors could contribute to differences in the chlorophyll-egg production relationship, including the variable relationship between chlorophyll and what the females are actually eating (including microzooplankton; Ohman \& Runge in press), the vertical distribution of prey, and the proportion of females in a pre- reproductive state. Nevertheless, the results shown in Fig. 7 support the idea that region-specific (in this case the Lower St. Lawrence Estuary), empirical relationships between chlorophyll standing stock and C. finmarchicus egg production rates have predictive value in studies of the Calanus-prey interactions

Comparison of egg production rates in the Lower Estuary with the laboratory observations must take into account possible temperature differences between laboratory incubations $\left(5.5^{\circ} \mathrm{C}\right)$ and the ambient environment. The mean equilibrium rate in the first $3 \mathrm{wk}$ of the laboratory experiment was 31 eggs female $e^{-1} \mathrm{~d}^{-1}$. Assuming that surface water temperatures $\left(7\right.$ to $9^{\circ} \mathrm{C}$ \} have a predominant influence on Calanus egg production and using the relationship between egg production and temperature developed by Runge (1985b), a mean rate of 40 to 50 eggs female ${ }^{-1} \mathrm{~d}^{-1}$ for well-fed females in summer would be predicted based on our laboratory results. This rate is equalled or surpassed by the Lower Estuary population, in contrast to the situation in Puget Sound, where egg production rates of C. pacificus were always less than the temperaturecorrected from laboratory experiments in which Thalassiosira weissflogii was also the sole source of food (Runge 1985a). A reduction in egg production rate after $3 \mathrm{wk}$ is similar to laboratory observations of C. pacificus (Runge 1984) and indicates either anset of senecence (Diel \& Tande 1992) or that T. weissflogii does not contain all the essential dietary elements necessary to sustain long-term egg production. It is possible as well that senescence (with respect to egg production) was brought on prematurely in the laboratory by the rapid decline in lipid reserves, if depot lipids are required for the early, generative phase of oogonial production, as discussed below. That a similar reduction in egg production was not also observed in the ambient environment suggests some combination of the following factors: (1) new females were being input into the Lower Estuary population; (2) wild females were ageing more slowly; or (3) the food composition in the Lower Estuary was more nutritious for $C$. finmarchicus than the laboratory food.

\section{Role of depot lipids in oocyte development}

The presence of a high proportion of females in stages 2 and 3 at the start of the study confirms that females realize the first steps of oogenesis well before the start of the spring bloom. While we cannot rule out the possibilty that female Calanus finmarchicus also sustain oocyte proliferation in early spring by ingesting suspended particulate material, including microzooplankton (e.g Butler et al. 1970, Corner et al. 1974 , 1976, Stoecker \& McDowell Capuzzo 1990), lipid 
reserves are a likely source of materials and energy during the early stages of development (Tande \& Hopkins 1981, Tande 1982). Moreover, the result that a small proportion of females develop oocytes to maturity in the absence of food (Fig. 3B) indicates that the capability of relying solely on internal reserves exists in the species. This could explain the presence of a small proportion of reproductively mature females in the Lower Estuary in April and May.

Results of our laboratory and field observations of oil sac depletion do not, however, provide unequivocal evidence for a relationship between lipid stores and oocyte development. The corresponding decline in both the depot lipid index and the proportion of stage 1 females before the spring bloom in the Lower Estuary population is consistent with the idea that lipid reserves support early stages of oogenesis. The rapid decline in lipid stores at the start of the phytoplankton bloom could represent either rapid development of stage 1 oocytes in remaining immature females or increased metabolic costs associated with feeding and other behaviour changes in response to the spring bloom. Laboratory experiments, however, show no difference between fed and unfed treatments in depletion of depot lipids. As previously mentioned, the rate of decline of lipid volume in the laboratory was much higher than in the natural environment; it is possible that the conditions of the experiments exacted an increased metabolic cost that masked the contribution of lipids to the early stages of oocyte development.

Our results therefore only allow several general conclusions with regard to the role of lipids in oogenesis: (1) the data do not rule out the possibility that lipid reserves were used to support the generative phase (i.e. proliferation of oogonia in the ovary) and early pre-vitellogenic growth of primary oocytes; and (2) prior to the spring bloom, the majority (but not necessarily all) of females did not use lipid reserves for secondary vitellogenesis (stages 4 to 7 ).

\section{Effects of temperature on the timing of egg production}

The purpose of the low temperature experiment was to understand the extent to which temperature variation in early spring may influence reproductive processes in the Lower Estuary. Interannual differences of several degrees centigrade have been observed in April-May in surface (e.g. Lacroix \& Filteau 1970) and deep (Budgen 1991) waters of the region; our choice of $1^{\circ} \mathrm{C}$ represents an extreme minimum that female Calanus finmarchicus would experience if they resided in the cold intermediate layer. The results show that, while the lower temperature reduces daily egg production rate, the start of egg production relative to the spring bloom was only $4 \mathrm{~d}$ later than the response of females incubated at $5.5^{\circ} \mathrm{C}$, a relatively short delay compared to the length of the spawning season. Therefore we conclude that interannual temperature variation in the Lower Estuary would have a minor influence on the timing of the copepod's reproductive cycle.

\section{The Lower St. Lawrence Estuary: a Calanus pump?}

Our results lead to the conclusion that the Lower St. Lawrence Estuary is a regionally important zone of Calanus finmarchicus reproduction. Although it commenced late, the spawning period of C. finmarchicus lasted over $12 \mathrm{wk}$, during which egg production reached the highest rates ever recorded for the species. The cycle of egg production is typically shorter and frequently episodic in other regions where $C$. finmarchicus predominates (e.g. Wiborg 1954, Marshall \& Orr 1955, Davis 1976, Williams \& Lindley 1980a, b, Tande et al. 1985, Skjoldal et al. 1987, Diel \& Tande 1992); maximum egg production rates are also sustantially lower, due to the smaller body size of the resident females. Although we do not yet have extensive measurements of the concentration of $C$. finmarchicus females in the Lower Estuary, this species is predominant in the region's zooplankton community and there is no indication that $C$. finmarchicus is any less abundant there than elsewhere (Runge \& Simard 1990).

A dominant feature of the surface circulation in the region is the Gaspé Current, a rapidly moving coastal jet moving the mass of the discharge from the St. Lawrence River out along the Estuary's southern side Net transport in the surface layer $(0$ to $30 \mathrm{~m})$ of the Lower Estuary is therefore outward to the Gulf of St. Lawrence (El-Sabh 1988). Fortier et al. (1992) observed high concentrations of copepod eggs (most of which would be Calanus spp.) and Calanus spp. copepodites in summer in the Gaspé Current as it leaves the Lower Estuary proper and rounds the Gaspé Peninsula into the Gulf of St. Lawrence. These concentrations are 1 to 2 orders of magnitude higher than in the adjacent Anticosti Gyre, reflecting differences in Calanus spp. production cycles between the Lower Estuary and Gaspe Current and waters of the Northern Gulf of St. Lawrence. Although there is not yet complete seasonal coverage of the phytoplankton production cycle in the Northern Gulf, there is every indication that the spring phytoplankton bloom typically ends by mid-June (de Lafontaine et al. 1991) and a stratified condition dominated by the microbial loop sets in for the summer months (Levasseur et al. 1992, Ohman \& Runge in press). While C. finmarchicus females continue to produce eggs in the Northern Gulf in early summer 
(June-July), egg concentrations in the water column are ca 5 times lower than in the Lower Estuary/Gaspé Current.

Hence, the evidence indicates that the Lower Estuary/Gaspé Current system acts as a Calanus 'pump', supplying fish larvae with abundant food (Fortier et al. 1992) and exporting zooplankton to the Gulf of St. Lawrence during the summer months. Examination of the residual surface circulation patterns in the Gulf (e.g. Koutitonsky \& Budgen 1991) suggests that some of the developing copepodites will drift with a branch of the Gaspé Current into the Southern Gulf of St. Lawrence; others will disperse into the nor thern gyres on the western and eastern sides of Anticosti Island. A portion of the current moves out through Cabot Strait along the southern side of the Laurentian Channel, where it becomes the Nova Scotia Current. Recent studies indicate that the Gulf of St. Lawrence is a major supplier of species of Calanus to populations on the Scotian Shelf (Herman et al. 1991, Sameoto \& Herman 1992). The Lower St. Lawrence Estuary may be the heart of a complex system that influences cycles of marine production over a wide region of eastern Canada.

Acknowledgements. We thank P. Joly, N. Turriff, J.-Y. Couture, E. Dionne, J.-F. St. Pierre, F. Villeneuve and the captain and the crew members of the 'F. G. Creed' for their support at sea and in the laboratory. We thank M. Starr, P. I. BladesEckelbarger and G. Lacroix who made valuable comments on the manuscript. This research was supported by the Department of Fisheries and Oceans Canada and by a grant from the Natural Sciences and Engineering Research Council, Canada, to J.A.R.

\section{LITERATURE CITED}

Arts, M. T., Evans, M. S. (1991). Optical-digital measurements of energy reserves in calanoid copepods: intersegmental distribution and seasonal patterns. Limnol. Oceanogr. 36: $289-298$

Budgen, G. L. (1991). Changes in the temperature-salinity characteristics of the deeper waters of the Gulf of St. Lawrence over the past several decades. In: Therriault, J.-C. (ed.) The Gulf of St. Lawrence: small ocean or big estuary? Can. Spec. Publ. Fish. Aquat. Sci. 113, p. 139-1.47

Butler, E. S., Corner, E. D. S., Marshall, S. M. (1970). On the nutrition and metabolism of zooplankton. VII. Seasonal survey of nitrogen and phosphorus excretion by Calanus in Clyde sea-area. J. mar, biol. Ass. U.K. 50: 525-560

Corner, E. D., Head, R. N., Kilvington, C. C., Marshall, S. M. (1974). On the nutrition and metabolism of zooplankton. IX. Studies relating to the nutrition of overwintering Calanus. J. mar. biol. Ass. U.K. 54: 319-331

Corner, E. D., Head, R. N. Kilvington, C. C., Pennycuick, L. (1976). On the nutrition and metabolism of zooplankton. $X$. Quantitative aspect of Calanus helgolandicus feeding as a carnivore. J. mar. Biol. Ass. U.K. 56: 345-358

Davis, C. C. (1976). Overwintering strategies of common planktonic copepods in some Norway fjords and sounds. Astarte 9: $37-42$ de Lafontaine, Y., Demers, S., Runge, J. A. (1991). Pelagic food web interactions and productivity in the Gulf of St. Lawrence: a perspective. In: Therriault, J.-C. (ed.) The Gulf of St. Lawrence: small ocean or big estuary? Can. Spec. Publ. Fish. Aquat. Sci. 113, p. 99-123

Diel, S., Tande, K. (1992). Does the spawning of Calanus finmarchicus in high latitudes follow a reproductive pattern? Mar. Biol. 113: 21-31

El-Sabh, M. I. (1988). Physical oceanography of the St. Lawrence Estuary. In: Kjerfve, B. (ed.) Hydrodynamics of estuaries, Vol. II. Estuarine cases studies. CRC Press, Boca Raton, p. 61-78

Fortier, L., Levasseur, M. E., Drolet, R., Therriault, J.-C. (1992). Export production and the distribution of fish larvae and their prey in a coastal jet frontal region. Mar. Ecol. Prog. Ser. 85: 203-218

Fransz, H. G. (1975). The spring development of calanoid copepod populations in the Dutch coastal waters as related to primary production. In: Persoone, G., Jaspers, E. (eds.) Proc. 10th Eur. Symp. mar. Biol. Universa Press, Wettern, 2: 247-249

Gatten, R. R., Corner, E. D. S., Kilvington, C. C., Sargent, J. R. (1979). A seasonal survey of the lipids in Calanus helgolandicus from the English Channel. In: Naylor, E., Hartnoll, R. G. (eds.) Cyclic phenomena in marine plants and animals. Pergamon Press. Oxford, p. 275-284

Gatten, R. R., Sargent, J. R., Forsberg, T. E. V., O'Hara, S. C. M., Corner, E. D. S. (1980). On the nutrition and metabolism of zooplankton. XIV. Utilisation of wax esters by Calanus helgolandicus during maturation and reproduction. J. mar. biol. Ass. U.K. 60: 391-399

Heinrich, A. K. (1962). The life histories of plankton animals and seasonal cycles of plankton communities in the oceans. J. Cons. perm. int. Explor. Mer 27: 15-24

Herman, A. W. Sameoto, D. D., Shunnian, C., Mitchell, M. R., Petrie, B., Cochrane, N (1991). Sources of zooplankton on the Nova Scotia Shelf and their aggregations within deepshelf basins. Cont. Shelf Res. 11: 211-238

Koutitonsky, V. G., Budgen, G. L. (1991). The physical oceanography of the Gulf of St. Lawrence: a review with emphasis on the synoptic variability of the motion. In: Therriault, J.-C. (ed.) The Gulf of St. Lawrence: small ocean or big estuary? Can. Spec. Publ. Fish. Aquat. Sci. 113 , p. $57-90$

Lacroix, G., Filteau, G. (1970). Les fluctuations quantitatives du zooplancton de la Baie-des-Chaleurs (Golfe du StLaurent). II. Composition des copépodes et fluctuation des copépodes du genre Calanus. Nat. Can. 97: 711-748

Levasseur, M., Fortier, L., Therriault, J.-C., Harrison, P. J. (1992). Phytoplankton dynamics in a coastal jet frontal region. Mar. Ecol. Prog. Ser. 86: 283-295

Levasseur, M., Therriault, J.-C., Legendre, L. (1984). Hierarchical control of phytoplankton succession by physical factors. Mar. Ecol. Prog. Ser 19: 211-222

Marshall, S. M., Orr, A. P. (1955). The biology of a marine copepod, Calanus finmarchicus (Gunnerus). Oliver and Boyd, London

McLaren, I. A., Sevigny, J.-M., Corkett, C. J. (1988) Body sizes, development rates, and genome sizes among Calanus species. Hydrobiologia 167/168: 275-284

Melle, W., Skjoldal, H. R. (1989). Zooplankton reproduction in the Barents Sea: vertical distribution of eggs and nauplii of Calanus finmarchicus in relation to a spring phytoplankton development. In: Ryland, J. S., Tyler, P. A. (eds.) Reproduction, genetics and distributions of marine organisms. Proc. 23rd Eur. mar. Biol. Symp., Olsen \& Olsen, Fredensborg, p. 137-145 
Miller, C. B., Cowles, T. J., Wiebe, P. H., Copley, N. J., Grigg, H. (1991). Phenology in Calanus finmarchicus; hypotheses about control mechanisms. Mar. Ecol. Prog. Ser 72: $79-91$

Ohman, M. D., Runge, J. A. (in press). Sustained fecundity when phytoplankton resources are in short supply: Calanus finmarchicus in the Gulf of St. Lawrence. Limnol. Oceanogr

Parsons, T. R., Maita, Y., Lalli, C. M. (1984). A manual of chemical and biological methods for seawater analysis. Pergamon Press, Oxford, p. 101-111

Peterson, W. T (1988). Rates of egg production by the copepod Calanus marshallae in the laboratory and in the sea off Oregon, USA. Mar. Ecol. Prog. Ser. 47: 229-237

Runge, J. A. (1984). Egg production of the marine, planktonic copepod, Calanus pacificus Broddsky: laboratory observations. J. exp. mar. Biol. Ecol. 74: 53-66

Runge, J. A. (1985a). Relationship of egg production of Calanus pacificus to seasonal changes in phytoplankton availability in Puget Sound, Washington. Limnol. Oceanogr. 30: 382-396

Runge, J. A. (1985b). Egg production rates of Calanus finmarchicus in the sea off Nova Scotia. Arch. Hydrobiol Beith. 21: 33-40

Runge, J. A. (1987). Measurement of egg production rate of Calanus finmarchicus from preserved samples. Can. J. Fish. Aquat. Sci. 44: 2009-2012

Runge, J. A., Simard, Y (1990). Zooplankton of the St. Lawrence Estuary: the imprint of physical processes on its composition and distribution In: El-Sabh, M. I., Silverberg N. (eds.) Coastal and estuarine studies, Vol. 39: oceanography of a large-scale estuarine system, the St. Lawrence. Springer-Verlag, New York, p. 296-320

Sameoto, D. D., Herman, A. W. (1992). Effect of the outflow from the Gulf of St. Lawrence on Nova Scotia shelf zooplankton. Can. J. Fish. Aquat. Sci. 49: 857-869

Sinclair, M., Subba Rao, D. V., Couture, R. (1981). Phytoplankton temporal distributions in estuaries. Oceanol. Acta $4: 239-246$

Skjoldal, H. R, Hassel, A., Rey, F, Loeng, H. (1987). Spring phytoplankton development and zooplankton reproduction in the central Barents Sea in the period 1979-1984. In Loeng, H. (ed.) The effect of oceanographic conditions on

This article was submitted to the editor distribution and population dynamics of commercial fish stocks in the Barents Sea. Proceedings of the third SovietNorwegian Symposium, Murmanks, 26-28 May 1989. Institute of Marine Research, Bergen, p. 59-80

Stein, J. R. (1973). Handbook of phycological methods. Cambridge University Press, Cambridge, p. 7-52, 234-252

Stoecker, D. K., McDowell Capuzzo, J (1990). Predation on protozoa: its importance to zooplankton. J. Plankton Res. 12: $891-908$

Tande, K. S. (1982). Ecological investigations of the zooplankton community of Balsfjorden, northern Norway: generation cycles, and variations in body weight and body content of carbon and nitrogen related to overwintering and reproduction in the copepod Calanus finmarchicus. J. exp. mar. Biol. Ecol. 62: 129-142

Tande, K. S., Hassel, A., Slagstad, D. (1985). Gonad maturation and possible life cycle strategies in Calanus finmarchicus and $C$ glacialis in the northwestern part of the Barent sea. In: Gray, J. S., Christiansen, M. E. (eds.) Biology of polar regions and effect of stress on marine organisims. J. Wiley \& Sons Ltd, New York, p. 141-155

Tande, K. S., Hopkins, C. C. E. (1981). Ecological investigations of the zooplankton community of Balsfjorden, northern Norway: the genital system in Calanus finmarchicus and the role of development in overwintering strategy. Mar. Biol. 63: 159-164

Therriault, J.-C., Levasseur, M. (1985). Control of phytoplankton production in the Lower St. Lawrence Estuary: light and freshwater runoff. Nat. Can 112:77-96

Tourangeau, S., Runge, J. A. (1991). Reproduction of Calanus glacialis under ice in spring in the southeastern Hudson Bay, Canada. Mar. Biol. 108: 227-233

Wiborg, K. F. (1954). Investigations on zooplankton in coastal and offshore waters of western and northwestern Norway. Report on Norwegian Fisheries and Marine Investigations, Vol. XI, No. l. A.S. John Griegs Boktrykker, p. 79-169

Williams, R., Lindley, J. A. (1980a). Plankton of the Fladen Ground during FLEX 76. I. Spring development of the plankton community. Mar. Biol. 57: 73-78

Williams, R., Lindley, J. A. (1980b). Plankton of the Fladen Ground during FLEX 76. III. Vertical distribution, population dynamics and production of Calanus finmarchicus (Crustacea: Copepoda). Mar. Biol 60: 47-56

Manuscript first received: April 13, 1993

Revised version accepted: October 7, 1993 